\title{
Efek Kinerja Keuangan Dan Kebijakan Keuangan Terhadap Nilai Perusahaan
}

\section{Agoestina Mappadang1, Jusuf Luther Mappadang, \& Agustinus Miranda Wijaya ${ }^{3}$}

${ }^{1}$ Fakultas Ekonomi dan Bisnis, Universitas Budi Luhur, DKI Jakarta 2Fakultas Teknik, Politeknik Negeri Manado; Sulawesi Utara ${ }^{2}$ ${ }^{3}$ Fakultas Ekonomi dan Bisnis, Universitas Pancasila, DKI Jakarta ${ }^{3}$

\begin{abstract}
This study is aimed to examine the effect of financial performance and financial policy using variables the Return on Equity (ROE), Return on Assets (ROA), Firm Size (SIZE), Debt to Equity Ratio (DER), and Earning per Share (EPS) towards firm value indicated by Price to Book Value $(P B V)$ of plantation sector companies listed in the Indonesia Stock Exchange. The data is obtained from the company's financial statements for the 2016-2020 consecutive year. The data was processed using Multiple Regression Analysis with SPSS 25. The results showed that ROE had a positive and significant effect on PBV. Return on Assets has a positive and significant effect on firm value, as indicated by PBV. Firm size has a positive but non-significant effect on firm value. The debt to Equity Ratio has a significant negative effect on firm value. Earning per share has a positive and significant effect on firm value.
\end{abstract}

\section{Keywords:}

Return on Equity (ROE), Return on Assets (ROA), Company Size (SIZE), Debt to Equity Ratio (DER), Earning per Share (EPS), and Price to Book Value

Corresponding Author:

Agoestina Mappadang

Fakultas Ekonomi dan Bisnis, Universitas Budi Luhur

Email: agustina.mappadang@budiluhur.ac.id

DOI: https://doi.org/10.36407/akurasi.v3i3.528

\section{Research Paper \\ Financial Management}

Received: 15 Oct 2021 Accepted: 20 Dec 2021

Online: 30 Dec 2021

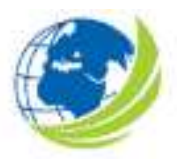

Akurasi: Jurnal Riset Akuntansi dan Keuangan, Vol 3, No.3, 2021, pp. 137 - 150

eISSN 2685-2888

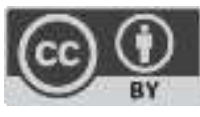

(C) The Author(s) 2021

CC BY This license allows reusers to distribute, remix, adapt, and build upon the material in any medium or format, so long as attribution is given to the creator. The license allows for commercial use. 


\section{PENDAHULUAN}

Pandemi Covid-19 sepanjang tahun 2020 telah melumpuhkan beberapa sektor industri, baik industri manufaktur, maupun industri perbankan dan jasa keuangan dan jasa lainnya. Dibalik itu, menariknya, sektor industri perkebunan kelapa sawit justru mencatatkan prestasi yang luar biasa sejalan dengan kenaikan harga dan iklim yang kondusif. Gabungan Industri Minyak Nabati Indonesia (GIMNI) memproyeksikan produksi minyak sawit mentah (crude palm oil/CPO) nasional pada 2021 akan tumbuh sekitar 3 persen menjadi 48,4 juta ton dari 2019 yang sebanyak 47 juta ton. Produksi minyak inti sawit (crude palm kernel oil/CPKO) juga akan meningkat sekitar 4 persen dari 4,6 juta ton menjadi 4,8 juta ton pada 2021. Peningkatan konsumsi biodiesel ini akan terjadi apabila program B30 terus berjalan dengan baik. Selain aspek domestik, volume ekspor minyak sawit nasional juga diperkirakan akan meningkat sekitar 11 persen menjadi 36,7 juta ton. Data Gabungan Pengusaha Kelapa Sawit Indonesia (GAPKI) mencatat, selama semester I2020 , produksi minyak sawit Indonesia dan turunannya tercatat sebesar 23,47 juta ton. Angka tersebut lebih rendah dibandingkan produksi semester I-2019 yang tercatat sebesar 25,88 juta ton. Investor akan berusaha memilih investasi yang menguntungkan yaitu dengan nilai perusahaan dari saham saham yang akan dipilih. Pengukuran nilai perusahaan merupakan indikator penting untuk melihat sejauh mana benefit yang akan didapatkan pemilik dana.

Price Earnings Ratio (PER) merupakan ukuran yang paling banyak digunakan untuk menentukan apakah investasi modal menguntungkan atau merugikan adalah Price Earnings Ratio (PER). Karena kesederhanaan dan kepraktisannya, serta adanya standar yang memudahkan investor untuk membandingkan penilaian terhadap perusahaan lain dalam industri yang sama, maka price earning ratio (PER) memiliki keuntungan antara lain. Hal ini menyebabkan para investor lebih mempertimbangkan Price Earning Ratio untuk digunakan dalam membantu mengidentifikasikan harga saham. Price Earning Ratio menunjukkan seberapa besar para investor bersedia dibayar untuk setiap keuntungan yang dilaporkan perusahaan sehingga merupakan salah satu alat untuk mengukur kinerja perusahaan. Para manajer keuangan akan senang jika saham perusahaannya dijual dengan Price Earning Ratio (PER) yang tinggi. Ini mengidentikasikan bahwa perusahaan mempunyai peluang pertumbuhan yang baik, yang berarti pendapatannya relatif aman dan sejalan dengan rendahnya tingkat kapitalisasi.

Salah satu cara mengukur nilai perusahaan adalah dengan rasio Price to Book Value (PBV). PBV merupakan perbandingan yang didapat antara harga saham dengan nilai buku dari saham perusahaan tersebut. Dengan menggunakan rasio PBV, calon investor bisa mengetahui perusahaan yang nilai sahamnya undervalued atau overvalued. Menurut Permata, et al,. (2013), nilai saham dikatakan undervalued ketika nilai PBV berada dibawah 1, dan overvalued ketika nilai PBV berada diatas 1 .

Indikator nilai perusahaan yang lain adalah Price to Book Value (PBV). Rasio harga pasar terhadap nilai buku (Price to Book Value) merupakan perbandingan antara harga pasar per lembar saham dengan nilai buku per lembar saham. Rasio ini membandingkan nilai pasar investasi pada perusahaan dengan biayanya. PBV juga menunjukkan seberapa jauh suatu perusahaan mampu menciptakan nilai perusahaan yang relatif terhadap jumlah modal yang diinvestasikan. Semakin tinggi rasio PBV dapat diartikan semakin berhasil perusahaan menciptakan nilai bagi pemegang saham. Price to Book value merupakan rasio yang digunakan untuk mengukur kinerja harga pasar saham terhadap nila 6 bukunya. PBV juga menunjukkan seberapa jauh perusahaan mampu menciptakan nilai perusahaan relatif terhadap jumlah modal yang diinvestasikan. Jika nilai buku suatu perusahaan meningkat maka nilai perusahaan yang ditunjukkan dengan harga saham akan meningkat pula (Nazmiyah et al,. 2014). 
Ukuran kinerja keuangan sangat penting untuk melihat sejauh mana kemampuan keuangan perusahaan yang diukur dengan menggunakan berbagai ratio keuangan diatanranya rasio profitabilitas dan rasio pertumbuhan. Selain ukuran kinerja keuangan, maka kebijakan keuangan yang digunakan perusahaan juga merupakan faktor internal yang sangat mendukung kinerja keuangan. Kebijakan keuangan perusahaan terdiri dari pengukuran rasio leverage dan rasio likuiditas. Ukuran kinerja keuangan dan ukuran kebijakan keuangan sangat mempengaruhi nilai perusahaan. Likuiditas, manajemen aset, manajemen utang, dan profitabilitas adalah variabelvariabel yang digunakan dalam beberapa penelitian sebelumnya juga dikaitkan dengan ukuran perusahaan. Oleh karena itu, penting untuk perusahaan mengetahui dan mempertimbangkan faktor-faktor yang mempengaruhi nilai perusahaan (Brigham \& Joel, 2010).

\section{KAJIAN PUSTAKA}

\section{Signaling theory}

Signaling theory menekankan kepada pentingnya informasi yang dikeluarkan oleh perusahaan terhadap keputusan investasi pihak di luar perusahaan. Informasi merupakan unsur penting bagi investor dan pelaku bisnis karena informasi pada hakekatnya menyajikan keterangan, catatan atau gambaran baik untuk keadaan masa lalu, saat ini maupun keadaan masa yang akan datang bagi kelangsungan hidup suatu perusahaan dan bagaimana pasaran efeknya. Informasi yang lengkap, relevan, akurat dan tepat waktu sangat diperlukan oleh investor di pasar modal sebagai alat analisis untuk mengambil keputusan investasi.

Bagi perusahaan yang go-public pemberian signal kepada investor dapat dilakukan dengan berbagai cara, misalnya pembagian cash dividen dalam jumlah besar akan mengisyaratkan bahwa perusahaan dalam kondisi keuangan yang baik, strategi ini akan sulit ditiru perusahaan yang mempunyai kondisi keuangan kurang baik. Demikian pula informasi perturmbuhan laba, pertumbuhan assets dan rasio debt to equity ratio dapat dijadikan signal bahwa perusahaan dalam kondisi keuangan yang baik dan perusahaan berupaya untuk menjaga keberlanjutannya.

Keterkaitan antara teori sinyal dengan EPS yaitu Laba atau earning menjadi perhatian investor karena laba yang dihasilkan perusahaan dapat menggambarkan keberhasilan perusahaan, maka semakin besar laba, semakin besar pula kemampuan perusahaan untuk membagikan keuntungan bagi pemegang sahamnya. Hal ini dapat meningkatkan permintaan akan saham, sehingga harga saham pun akan naik, di mana hasil ini sesuai dengan signaling theory yang memberikan sinyal baik pada investor. Nilai PBV akan tinggi apabila kinerja perusahaan baik. Hal ini berarti semakin baik kinerja perusahaan, maka rasio PBV akan semakin meningkat dari tahun ke tahun. Tingginya permintaan akan menyebabkan harga saham meningkat (Cahyaningrum \& Antikasari, 2017).

Hubungan teori sinyal dengan ROA yaitu apabila nilai ROA meningkat, maka ini berarti perusahaan mampu menggunakan aktivanya secara produktif sehingga dapat menghasilkan keuntungan yang besar. Hal ini dapat dijadikan signal untuk para investor dalam memprediksi seberapa besar perubahan nilai atas saham yang dimiliki. ROE memiliki hubungan dengan teori sinyal apabila ROE meningkat, maka dapat diasumsikan perusahaan mampu menunjukkan efisiensi dalam penggunaan modal sendiri. Hal ini dapat dijadikan signal yang baik bagi para investor untuk membeli saham. Model penelitian yang dibuat dalam penelitian ini seperti pada gambar 1 


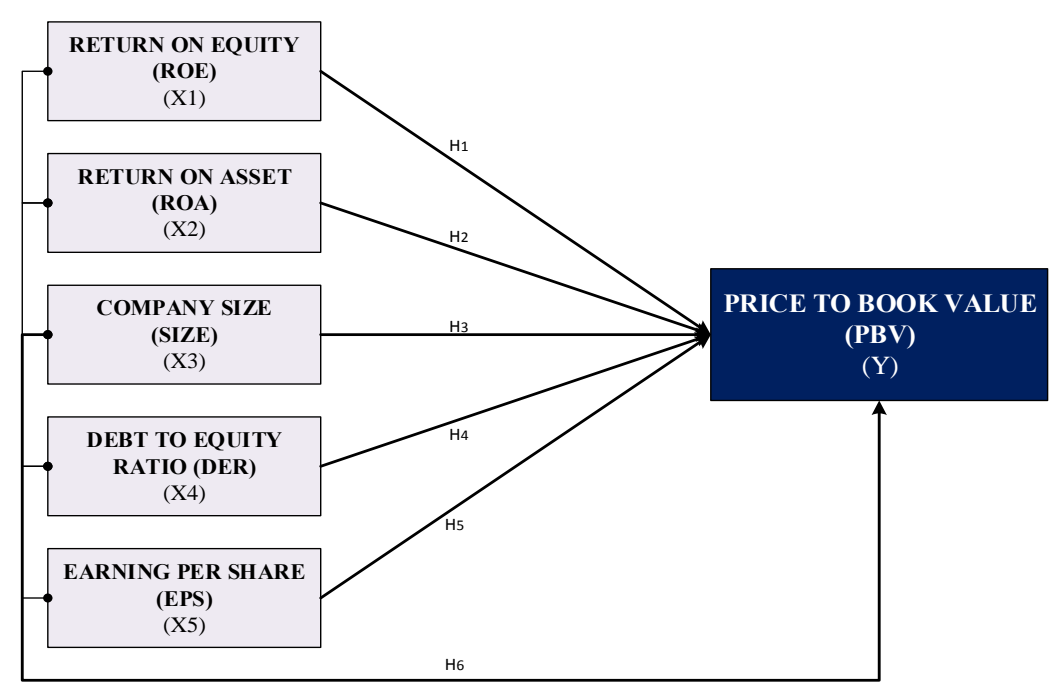

Gambar 1

Model penelitian

\section{Pengembangan Hipotesis}

Rasio Return On Asset (ROA) ini sering digunakan pihak manajemen untuk mengukur kinerja keuangan perusahaan dan menilai kinerja operasional dalam memanfaatkan sumber daya yang dimiliki. Jika perusahaan mendapatkan keuntungan dari penggunaan seluruh aset (sumber daya) maka nilai perusahaan yang ditunjukkan dengan harga saham akan meningkat pula. Penelitian yang dilakukan oleh Murniati (2016) pada variabel Return On Asset (ROA) menunjukkan bahwa ada hubungan signifikan positif antara ROA dengan harga saham perusahaan. Hasil ini didukung oleh hasil penelitian Thim et al. (2012) dan Haque et al. (2012). Hasil penelitian ini berbeda dengan penelitian yang dilakukan oleh Satryo et al. (2016) menunjukkan bahwa secara parsial variabel ROA tidak berpengaruh secara signifikan terhadap harga saham. Hipotesis yang terbentuk adalah:

H2: Return on Asset (ROA) secara parsial berpengaruh positif dan signifikan terhadap nilai perusahaan yang diindikasikan oleh Price to Book Value (PBV).

Agar dapat melangsungkan aktivitas operasinya, suatu entitas haruslah berada dalam keadaan yang menguntungkan (profitable), karena tanpa adanya keuntungan akan sulit bagi perusahaan untuk menarik modal dari luar. Perusahaan yang memiliki tingkat profitabilitas yang tinggi diminati sahamnya oleh investor, sehingga, dengan demikian profitabilitas dapat mempengaruhi nilai perusahaan. Menurut Mardiyati (2012), profitabilitas memiliki pengaruh yang positif signifikan terhadap nilai perusahaan. Profit yang tinggi memberikan indikasi prospek perusahaan yang baik sehingga dapat memicu investor untuk ikut meningkatkan permintaan saham. Permintaan saham yang meningkat menyebabkan nilai perusahaan yang meningkat. Hal tersebut juga sejalan dengan penelitan yang dilakukan oleh Wahyudi (2016), variabel ROE mempunyai hubungan dan pengaruh positif terhadap nilai perusahaan.

Return on equity biasanya diikuti oleh kenaikan harga saham perusahaan. Semakin tinggi return on equity berarti semakin baik kinerja perusahaan dalam mengelola modalnya untuk menghasilkan keutungan bagi pemegang saham, dapat dikatakan bahwa perusahaan tersebut dapat menggunakan modal dari pemegang saham secara efektif dan efisien untuk memperoleh laba, dengan adanya pengingkatan laba bersih maka nilai return on equity akan meningkat pula 
sehingga para investor tertarik untuk membeli saham tersebut yang akhirnya harga saham perusahaan tersebut mengalami kenaikan (Christina, et al,. 2016). Hasil penelitian-penelitian sebelumnya dapat dibuat hipotesis sebagai berikut:

H2: Return on Equity (ROE) secara parsial berpengaruh positif dan signifikan terhadap nilai perusahaan yang diindikasikan oleh Price to Book Value (PBV).

Ukuran perusahaan adalah salah satu variabel yang dipertimbangkan dalam menentukan nilai suatu perusahaan. Ukuran perusahaan merupakan cerminan total dari aset yang dimiliki suatu perusahan. Perusahaan sendiri dikategorikan menjadi dua jenis, yaitu perusahaan berskala kecil dan perusahaan berskala besar. Menurut Wahyudi (2016), Variabel Firm Size (FS) tidak berpengaruh terhadap Nilai Perusahaan (PBV) akan tetapi berkorelasi positif terhadap nilai Perusahaan (PBV). Rumondor (2015) berkesimpulan bahwa ukuran perusahaan berpengaruh tidak signifikan terhadap nilai perusahaan. Namun Hal tersebut tidak sejalan dengan penelitian yang dilakukan oleh Pratama (2016) dimana ukuran perusahaan secara parsial berpengaruh positif signifikan terhadap nilai Perusahaan. Hipotesis yang dikembangkan dalam penelitian ini yaitu:

H3: Ukuran Perusahaan (SIZE) secara parsial berpengaruh positif dan signifikan terhadap nilai perusahaan yang diindikasikan oleh Price to Book Value (PBV)

Rahayu \& Sari (2018) menyatakan bahwa kebijakan hutang dapat dihubungkan dengan nilai perusahaan, dimana kebijakan hutang merupakan kebijakan perusahaan tentang seberapa jauh sebuah perusahaan menggunakan pendanaan yang bersumber dari hutang. Mengacu pada trade off theory menjelaskan bahwa semakin tinggi perusahaan melakukan pendanaan dengan hutang maka semakin besar pula resiko mereka untuk mengalami kesulitan keuangan karena membayar bunga tetap yang terlalu besar bagi para debt-holders setiap tahunnya dengan kondisi laba bersih yang belum pasti. Debt to equity ratio (DER) merupakan rasio yang digunakan untuk menilai utang dengan ekuitas. Rasio ini berguna untuk mengetahui jumlah dana yang disedikan peminjama dengan pemilik perusahaan. Semakin besar nilai DER menandakan bahwa struktur permodalan usaha lebih banyak bersumber dari utang dibandingkan dari ekuitas, sehingga semakin tinggi DER mencerminkan risiko perusahaan yang relatif tinggi, akibatnya investor cenderung menghindari sahamsaham yang memiliki DER yang tinggi. Brigham \& Houston, (2014) menyatakan bahwa semakin tinggi debt to equity ratio, maka semakin berisiko bagi perusahaan (kemungkinan perusahaan tidak dapat membayar semua utangnya).

Keuntungan penggunaan hutang diperoleh dari pajak yaitu pembayaran bunga pinjaman dapat digunakan sebagai pengurangan pajak, sedangkan kerugian penggunaan hutang berhubungan dengan timbulnya biaya keagenan dan biaya kepailitan. Mardiyati (2012) berkesimpulan bahwa kebijakan hutang berpengaruh positif tetapi tidak signifikan terhadap nilai perusahaan. Hal tersebut sejalan dengan penelitian yang dilakukan oleh Pratiwi (2016) yang menyatakan bahwa terdapat pengaruh struktur modal terhadap nilai perusahaan. Hipotesis yang terbentuk dari hasil pemaparan penelitian terdahulu yaitu:

H4: Debt to Equity Ratio (DER) secara parsial berpengaruh negatif dan signifikan terhadap nilai perusahaan yang diindikasikan oleh Price to Book Value (PBV).

Earning Per Share (EPS) merupakan bagian proporsional dari laba perusahaan pertahun yang dapat diklaim oleh setiap lembar saham yang sedang beredar, yang dihitung dengan membagi laba setelah pajak sesudah pembayaran dividen saham preferen dengan rata-rata saham biasa yang sedang beredar selama periode tersebut yang dinyatakan dalam satuan rupiah. Penelitian 
Wulandari (2016), Pamungkas (2018) mengatakan, Investor dapat mengetahui besarnya pertumbuhan earning yang telah dicapai perusahaan terhadap jumlah saham perusahaan. Semakin besar tingkat kemampuan perusahaan menghasilkan keuntungan perlembar saham maka semakin baik kinerja perusahaan yang diakibatkan dengan tingginya tingkat EPS, hal ini dapat mempengaruhi perubahan return saham. Berbeda halnya dengan hasil penelitian Risdiyanto dan Suhermin (2016) EPS tidak berpengaruh baik simultan maupun parsial. Wulandani (2016) menemukan pengaruh laba (Earning Per Share) dan Price to Book Value (PBV) terhadap return saham. Dengan kata lain beberapa rasio akuntansi ini mempunyai kandungan informasi yang relevan sebagai alat pengambilan keputusan investasi. Hasil penelitian ini diperkuat oleh Pamungkas (2018) menemukan adanya pengaruh signifikan Laba (EPS) dan PBV terhadap return saham. Riyanti (2012), menemukan bahwa informasi laba (EPS) berpengaruh posiitif terhadap return saham pasca IPO jangka panjang, dimana ukuran EPS mencerminkan besaran nilai uang yang diterima oleh pemilik saham (shareholder). Sehingga semakin besar EPS maka berdampak pada keuntungan (return) yang semakin tinggi bagi pemegang saham. Hasil penelitian-penelitian sebelumnya dapat dibuat hipotesis sebagai berikut:

H5: Kinerja saham yang diindikasikan oleh Earnings per Share (EPS) secara parsial berpengaruh positif dan signifikan terhadap nilai perusahaan yang diindikasikan oleh Price to Book Value (PBV).

\section{METODE}

Penelitian ini dapat dikategorikan sebagai eksplanatory (explanatory research) dengan pendekatan kuantitatif (Sekaran, 2016). Penelitian berupaya menjelaskan inter-relasi dari beberapa variabel yang diidentifikasi dari fenomena atau dengan kata lain pengaruh dari beberapa variabel independen: Return on Asset (ROA), Return on Equity (ROE), Ukuran Perusahaan (SIZE), Debt to Equity Ratio (DER), dan Earning per Share (EPS) terhadap nilai perusahaan yang diindikasikan oleh Price to Book Value (PBV) pada Perusahaan Sektor Perkebunan yang Terdaftar di Bursa Efek Indonesia (BEI). Populasi penelitian ini adalah seluruh Sektor Perkebunan - Kelapa Sawit (Plantation) yang terdaftar pada Bursa Efek Indonesia (BEI) dengan periode pengamatan antara tahun 2016 - 2020. Data yang digunakan dalam penelitian ini merupakan data sekunder. Analisis regresi logistic digunakan sebagai alat analisis statistik karena penelitian ini dirancang untuk meneliti pengaruh dari variabel independen terhadap variabel dependen, dimana variabel dependen (bebas) yang digunakan lebih dari satu, dengan menggunakan variabel kategori. Perumusan model analisis statistik yang digunakan dapat dirumuskan berikut:

$$
Y=\alpha+\beta_{1} \beta X_{1}+\beta_{2} X_{2}+\beta_{3} X_{3}+\beta_{4} X_{4}+\beta_{5} X_{5}+\varepsilon
$$

Notasi:

$\mathrm{Y} \quad=$ Price to Book Value (PBV)

$\mathrm{a} \quad=$ Konstanta (Constant)

$\beta=$ Koefisien Regresi

$\mathrm{X}_{1}=$ Return on Equity (ROE)

$\mathrm{X}_{2}=$ Return on Asset (ROA)

$\mathrm{X}_{3}=$ Company Size (SIZE)

$\mathrm{X}_{4}=$ Debt to Equity Ratio (DER)

$\mathrm{X}_{5} \quad=$ Earning per Share (EPS)

$\varepsilon \quad=$ Standard Error (Error Term) 


\section{Definisi Operasional dan Pengukuran Variabel}

Variabel independen dalam penelitian ini meliputi, Return on Equity (ROE), Return on Equity (ROE), Company Size (SIZE), Debt to Equity Ratio (DER), dan Earning per Share (EPS). Definisi dan pengukuran masing-masing variabel menurut (Brigham, 2001) dapat dijelaskan sebagai berikut:

Return on Equity (ROE)

Return on Equity (ROE) merupakan rasio yang digunakan untuk mengukur kemampuan perusahaan memperoleh laba dari ekuitas yang dimiliki oleh perusahaan. Rasio ini membandingkan laba bersih dengan total equity yang dimiliki perusahaan. Variabel ini diukur dengan menggunakan persamaan seagai berikut:

Return on Equity $=\frac{\text { Net Profit }}{\text { Total Equity }}$

Return on Asset (ROA)

Return on Asset (ROA) merupakan rasio yang digunakan untuk mengukur kemampuan perusahaan memperoleh laba dari total asset yang dimiliki oleh perusahaan. Rasio ini membandingkan laba bersih dengan total asset yang dimiliki perusahaan. Variabel ini diukur dengan menggunakan persamaan seagai berikut:

Return on Equity $=\frac{\text { Net Profit }}{\text { Total Asset }}$

Company SIZE (SIZE)

Ukuran perusahaan (SIZE) diindikasikan oleh total asset yang dimiliki oleh perusahaan. Variabel ini diukur dengan menggunakan persamaan seagai berikut:

Company Size $=$ Ln Total Asset

Debt to Equity Ratio (DER)

Debt to Equity Ratio menunjukkan bagaimana kemampuanperusahaan menggunakan modal yang ada dalam memenuhi kewajibannya. Variabel ini diukur dengan menggunakan persamaan seagai berikut:

Debt to Equity $=\frac{\text { Total Debt }}{\text { Total Equity }}$

Earning per Share (EPS)

Earning per Share (EPS) merupakan laba yang diperoleh oleh investor dari setiap lembar saham yang diinvestasikan. Variabel ini diukur dengan membagi net profit dengan jumlah saham yang diterbitkan. Variabel ini diukur dengan menggunakan persamaan seagai berikut:

Earning per Share $=\frac{\text { Net Profit }}{\text { Total Share Issued }}$ 


\section{Price to Book Value (PBV)}

Price to Book Value (PBV) ditunjukkan dengan perbandingan antara harga sahamterhadap nilai buku dihitung sebagai hasil dari ekuitas pemegang saham dengan jumlah saham yang beredar. Variabel ini diukur dengan menggunakan persamaan seagai berikut:

Price to Book Value $=\frac{\text { Closing Price }}{\text { Book Value per share }}$

\section{HASIL DAN PEMBAHASAN}

\section{Uji Kecocokan Model}

F test digunakan untuk menunjukkan apakah variabel independen yang digunakan dalam model penelitian secara serentak memiliki pengaruh signifikan terhadap variabel dependen. Hipotesis dapat diterima apabila nilai dari $\mathrm{F}_{\text {hitung }}$ lebih besar dari $\mathrm{F}_{\text {tabel. }}$. Derajat kesalahan yang ditoleransi sebesar 0.05 dan derajat keyakinan (confidence interval) sebesar 0.95 atau taraf signifikansi yang digunakan dalam analisis ini sebesar 0.05. Apabila nilai sig lebih kecil dari 0.05, maka pengaruh variabel independen terhadap variabel dependen dapat dinyatakan signifikan dan hipotesis dapat diterima. Hasil uji F selengkapnya dapat dilihat pada tabel 1.

\section{Tabel 1}

\section{Hasil Uji F}

\begin{tabular}{|l|l|r|r|r|r|r|}
\hline \multicolumn{2}{|c|}{ Model } & Sum of Squares & df & $\begin{array}{c}\text { Mean } \\
\text { Square }\end{array}$ & F & Sig. \\
\hline \multirow{3}{*}{1} & Regression & 73.758 & 5 & 14.752 & 42.963 & $.000^{\mathrm{b}}$ \\
\cline { 2 - 7 } & Residual & 32.275 & 94 & 0.343 & & \\
\cline { 2 - 7 } & Total & 106.033 & 99 & & & \\
\hline
\end{tabular}

a. Dependent Variable: PBV

b. Predictors: (Constant), EPS, ROA, ROE, SIZE, DER

Nilai signifikan $\mathrm{F}$ atau $\mathrm{F}_{\text {hitung }}$ menunjukkan signifikansi koefisien determinan atau membuktikan kecocokan model regresi, artinya persamaan regresi yang dihasilkan mampu menjelaskan variasi

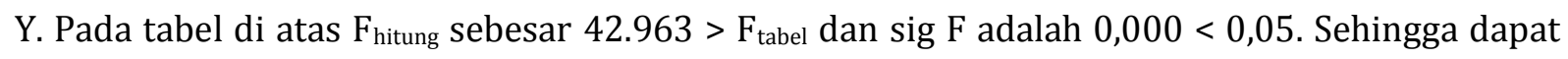
disimpulkan bahwa model yang digunakan sesuai dengan model yang dikembangkan dan hasil analisis dapat digeneralisasikan pada populasi dengan derajat kesalahan 5\% dan derajat keyakinan 95\%. Dari tabel di atas, apabila tingkat signifikan $\alpha=5 \%$ dengan uji dua arah dk (n-K1) atau (100-5-1) = 94, terdapat di tabel distrtibusi $F_{94}=2.069$ dan dari tabel Uji $F$ di atas dapat dilihat nilai $\mathrm{F}$ hitung berdasarkan hasil perhitungan SPSS 25 adalah sebesar 42.963. Dengan demikian ( $F_{\text {hitung }} 42.963>F_{\text {tabel }}$ 2.069), sehingga jelas $\mathrm{H}_{\mathrm{o}}$ ditolak dan $\mathrm{H}_{\mathrm{a}}$ diterima. Hal ini menunjukkan bahwa variabel Return on Asset (ROA), Return on Equity (ROE), Ukuran Perusahaan (SIZE), Debt to Equity Ratio (DER), dan Earning per Share (EPS) secara bersama-sama berpengaruh terhadap nilai perusahaan yang diindikasi kan oleh Price to Book Value (PBV)..

\section{Pengujian Hipotesis Parsial}

Uji t digunakan untuk menunjukkan seberapa besar pengaruh suatu variabel independen atau variabel bebas secara invidual terhadap variabel dependen atau variabel terikat secara parsial (Ghozali 2016). Uji t ( $t$-test) digunakan untuk menguji apakan variabel independen yang digunakan dalam model penelitian secara parsial memiliki pengaruh signifikan terhadap variabel 
dependen. Hipotesis dapat diterima apabila nilai dari $t_{\text {hitung }}$ lebih besar dari $t_{\text {tabel. }}$. Derajat kesalahan yang ditoleransi sebesar 0.05 dan derajat keyakinan (confidence interval) sebesar 0.95. taraf signifikansi yang digunakan dalam analisis ini sebesar 0.05 . Hasil uji t selengkapnya dapat dilihat pada Tabel 2.

Tabel 2

Hasil Uji t (Parsial)

\begin{tabular}{|c|c|c|c|c|c|c|c|c|}
\hline & \multirow{2}{*}{ Model } & \multicolumn{2}{|c|}{$\begin{array}{l}\text { Unstandardized } \\
\text { Coefficients }\end{array}$} & \multirow{2}{*}{$\begin{array}{c}\begin{array}{c}\text { Standardized } \\
\text { Coefficients }\end{array} \\
\text { Beta }\end{array}$} & \multirow{2}{*}{$t$} & \multirow{2}{*}{ Sig. } & \multicolumn{2}{|c|}{ Collinearity Statistics } \\
\hline & & $\mathrm{B}$ & Std. Error & & & & Tolerance & VIF \\
\hline \multirow[t]{6}{*}{1} & (Constant) & -8.126 & 5.345 & & -1.520 & 0.132 & & \\
\hline & ROE & 27.804 & 4.032 & 0.565 & 6.896 & 0.000 & 0.483 & 2.071 \\
\hline & ROA & 9.282 & 3.997 & 0.141 & 2.322 & 0.022 & 0.875 & 1.143 \\
\hline & SIZE & 0.134 & 0.177 & 0.065 & 0.760 & 0.449 & 0.440 & 2.273 \\
\hline & DER & -7.552 & 2.063 & -0.766 & -3.660 & 0.000 & 0.074 & 13.540 \\
\hline & EPS & 0.589 & 0.257 & 0.462 & 2.286 & 0.024 & 0.079 & 12.629 \\
\hline
\end{tabular}

Berdasarkan hasil uji t (parsial) di atas dapat dijelaskan beberapa hal sebagai berikut: Variabel return on equity (ROE) memiliki pengaruh positif terhadap nilai perusahaan yang diindikasikan oleh price to book value (PBV) sebesar 27,804 dengan nilai $t_{\text {hitung }}$ sebesar 6.896 dan nilai signifikansi 0.000 (positif signifikan). Dengan demikian hipotesis 1 yang menyatakan bahwa return on equity (ROE) secara parsial memiliki pengaruh positif dan signifikan terhadap nilai perusahaan yang diindikasikan oleh price to book value (PBV) secara statistik diterima.

Variabel return on asset (ROA) memiliki pengaruh positif terhadap nilai perusahaan yang diindikasikan oleh price to book value (PBV) sebesar 9,282 dengan nilai $t_{\text {hitung }}$ sebesar 2.322 dan nilai signifikansi 0.022 (positif signifikan). Dengan demikian hipotesis 2 yang menyatakan bahwa return on asset (ROA) secara parsial memiliki pengaruh positif dan signifikan terhadap nilai perusahaan yang diindikasikan oleh price to book value (PBV) secara statistik diterima.

Variabel ukuran perusahaan (SIZE) memiliki pengaruh positif terhadap nilai perusahaan yang diindikasikan oleh price to book value (PBV) sebesar 0,134 dengan nilai $t_{\text {hitung }}$ sebesar 0.760 dan nilai signifikansi 0.449 (positif tidak signifikan). Dengan demikian hipotesis 3 yang menyatakan bahwa ukuran perusahaan (SIZE) secara parsial memiliki pengaruh positif dan signifikan terhadap nilai perusahaan yang diindikasikan oleh price to book value (PBV) secara statistik ditolak.

Variabel debt to equity ratio (DER) memiliki pengaruh negatif terhadap nilai perusahaan yang diindikasikan oleh price to book value (PBV) sebesar -7,552 dengan nilai $t_{\text {hitung }}$ sebesar -3.660 dan nilai signifikansi 0.000 (negatif signifikan). Dengan demikian hipotesis 4 yang menyatakan bahwa debt to equity ratio (DER) secara parsial memiliki pengaruh negatif dan signifikan terhadap nilai perusahaan yang diindikasikan oleh price to book value (PBV) secara statistik diterima.

Variabel earning per share (EPS) memiliki pengaruh positif terhadap nilai perusahaan yang diindikasikan oleh price to book value (PBV) sebesar 0,589 dengan nilai $t_{\text {hitung }}$ sebesar 2.286 dan nilai signifikansi 0.024 (positif signifikan). Dengan demikian hipotesis 5 yang menyatakan bahwa earning per share (EPS) secara parsial memiliki pengaruh positif dan signifikan terhadap nilai perusahaan yang diindikasikan oleh price to book value (PBV) secara statistik diterima. 


\section{Pembahasan}

Nilai perusahaan merupakan aspek utama yang dipertimbangkan oleh investor sebelum mereka memutuskan untuk menginvestasikan dana di suatu perusahaan. Peningkatan nilai perusahaan dari tahun ke tahun merupakan suatu gambaran keberhasilan manajemen perusahaan dalam menjalankan usahanya. Nilai perusahaan yang tinggi akan seiring dengan tingginya kemakmuran pemegang saham. Nilai perusahaan dapat dipengaruhi oleh beberapa faktor, antara lain kemampuan perusahaan mengahsilkan laba, kebijakan hutang yang dilakukan perusahaan, ukuran perusahaan dan pendapatan per lembar saham.

Profitabilitas merupakan sebuah gambaran bagaimana suatu perusahaan dapat mengahsilkan keuntungan dari asset ataupun ekuitas yang mereka miliki. Profitabilitas yang tinggi menandakan bahwa perusahaan tersebut dapat menghasilkan tingkat keuntungan yang tinggi pula. Tingginya rasio profitabilitas akan menjadi daya tarik utama bagi investor yang ingin menanamkan modal. Semakin tinggi minat para investor kepada suatu perusahan tentunya akan meningkatkan harga saham perusahaan tersebut. Hasil penelitian ini mengkonfirmasi bahwa profitabiltias yang diindikasikan oleh return on equity (ROE) dan return on asset (ROA) mempengaruhi nilai perusahaan yang diindikasikan oleh price to book value (PBV).

Return on equity (ROE) sering disebut juga return on common equity sering diterjemahkan sebagai rentabilitas saham sendiri (rentabilitas modal saham). Investor yang akan membeli saham akan tertarik dengan Return On Equity (ROE) yaitu bagian dari total profitabilitas yang bisa dialokasikan ke pemegang saham. Oleh karena itu semakin tinggi Return On Equity (ROE) maka akan semakin tinggi juga Price to book value (PBV) sebagai ukuran dari nilai perusahaan. Sebaliknya semakin kecil Return On Equity (ROE) maka semakin kecil Price to book value (PBV). Apabila saham perusahaan diperdagangkan di bursa saham, tinggi rendahnya Return on Equity akan mempengaruhi tingkat permintaan saham tersebut di bursa dan harga jualnya. Hal ini dikarenakan Return on Equity merupakan tolak ukur profitabilitas dimana para pemegang saham pada umumnya ingin mengetahui tingkat probabilitas modal saham yang telah mereka tanam dalam persahaan dan besarnya keuntungan yang mereka peroleh.

Ukuran perusahaan dalam penelitian ini berpengaruh positif tetapi tidak signifikan terhadap nilai perusahaan yang diindikasikan oleh price to book value (PBV). Hasil ini tidak sejalan dengan penelitian Wahyuni et al.. (2013) yang menyatakan bahwa semakin besar ukuran perusahaan maka semakin besar keyakinan investor akan kemampuan perusahaan dalam memberika tingkat pengembalian investasi. Hal ini dikarenakan semakin besar suatu perusahaan, tentunya kondisi perusahaan tersebut akan semakin stabil. Dengan harapan mendapat keuntungan yang lebih tinggi, tentunya investor akan lebih memilih untuk berinvestasi pada perusahaan yang besar. Arfianto \& Chabachib (2016) menyimpulkan bahwa Size berpengaruh signifikan terhadap PBV perusahaan yang terdaftar dalam indeks LQ-45 periode 2011-2014. Hal ini dikarenakan nilai sig. Yang lebih kecil dari 0,05 yaitu sebesar 0,015. Hasil persamaan regresi menunjukan bahwa variabel Size memiliki koefisien regresi positif, maka dapat diartikan bahwa Size memiliki hubungan searah terhadap PBV.

Debt to equity ratio berpengaruh negatif dan signifikan terhadap nilai perusahaan yang diindikasikan oleh price to book value (PBV). Nilai perusahaan yang diindikasikan oleh price to book value (PBV). Hasil ini sejalan dengan Weston dan Copeland (2010) yang menyatakan menyatakan bahwa rasio leverage yang tinggi dapat menurunkan nilai perusahaan. Hal ini dikarenakan rasio leverage yang tinggi menandakan bahwa perusahaan tersebut memiliki rasio hutang yang lebih tinggi dibandingkan dengan total asetnya. Leverage itu sendiri dapat diartikan 
sebagai penaksir dari resiko yang melekat pada suatu perusahaan. Artinya, rasio leverage yang semakin tinggi menunjukkan risiko investasi yang semakin besar pula.

Earning per Share (EPS) dalam penelitian ini berpengaruh positif signifikan terhadap nilai perusahaan yang diindikasikan oleh price to book value (PBV). Hasil penelitian ini mengindikasikan bahwa Earning per Share (EPS) yang naik mencerminkan hasil investasi per lembar saham meningkat, sehingga kepercayaan investor meningkat dan harga saham juga meningkat, dampak akhirnya Price to book value ( PBV) juga meningkat. Sebaliknya bila Earning per Share (EPS) turun, investor enggan untuk membeli saham, kondisi ini akan berakibat harga saham juga akan turun. Turunnya harga saham akan berakibat pada turunnya Price to book value ( PBV) . Hasil ini tidak sejalan dengan Suherman \& Siburian (2013) yang mengindikasikan bahwa laba per lembar saham secara parsial tidak berpengaruh terhadap return saham. Hasil ini bertentangan dengan teori yang mendasarinya bahwa EPS yang semakin besar akan menunjukkan bahwa kemampuan perusahaan dalam menghasilkan laba bersih setelah pajak semakin meningkat, dengan meningkatnya laba bersih setelah pajak yang dihasilkan oleh perusahaan maka total return yang diterima oleh para pemegang saham juga semakin meningkat. Wardiningsih (2019) berkesimpulan bahwa Earning Per Share (EPS) berpengaruh positif terhadap return saham, berarti bahwa dengan menggunakan rasio EPS, investor dapat mengetahui besarnya pertumbuhan earning yang telah dicapai oleh perusahaan terhadap jumlah saham perusahaan. Semakin besar tingkat kemampuan perusahaan menghasilkan keuntungan perlembar saham maka semakin baik kinerja perusahaan yang diakibatkan dengan tingginya tingkat EPS, hal ini dapat mempengaruhi perubahan return saham. Hasil penelitian ini konsisten dengan penelitian yang dilakukan oleh Riyanti (2012), Wulandani (2016) dan Pamungkas (2018) dengan hasil Earning Per Share (EPS) berpengaruh secara signifikan terhadap return saham.

\section{KESIMPULAN}

Berdasarkan analisis data dan pembahasan di atas dapat ditarik beberapa kesimpulan yaitu Return on Equity (ROE) berpengaruh positif dan signifikan terhadap nilai perusahaan sektor perkebunan yang terdaftar di BEI yang diindikasikan oleh price to book value (PBV). Semakin tinggi return on equity (ROE), semakin tinggi pula nilai perusahaan yang bersangkutan. Return on Asset (ROA) berpengaruh positif dan signifikan terhadap nilai perusahaan sektor perkebunan yang terdaftar di BEI yang diindikasikan oleh price to book value (PBV). Semakin tinggi return on asset (ROA), semakin tinggi pula nilai perusahaan yang bersangkutan. Ukuran perusahaan (SIZE) berpengaruh positif tetapi tidak signifikan terhadap nilai perusahaan sektor perkebunan yang terdaftar di BEI yang diindikasikan oleh price to book value (PBV).Debt to Equity Ratio (DER) berpengaruh negatif dan signifikan terhadap nilai perusahaan sektor perkebunan yang terdaftar di BEI yang diindikasikan oleh price to book value (PBV). Semakin tinggi ratio hutang, semakin turun nilai perusahaan. Earning per Share (EPS) berpengaruh positif dan signifikan terhadap nilai perusahaan sektor perkebunan yang terdaftar di BEI yang diindikasikan oleh price to book value (PBV). Semakin tinggi Earning per Share (EPS), semakin tinggi pula nilai perusahaan yang bersangkutan.

\section{Keterbatasan}

Penelitian ini memiliki beberapa keterbatasan yang dapat diuraikan sebagai berikut: Pertama, penelitian ini dilakukan hanya pada satu sektor yaitu pada perusahaan sektor perkebunan kelapa sawit yang terdaftar di Bursa Efek Indonesia. Untuk dapat digeneralisasi, penelitian selanjutnya dapat menggunakan sampel perusahaan dari berbagai sektor. Kedua, goodness fit index dari 
model ini yang tercermin dari koefisien determinasi pada angka 69,6\%, artinya sebesar 30,4\% masih memungkinkan untuk menggunakan variabel-variabel lain untuk memprediksi nilai perusahaan. Dalam terminologi yang lebih umum nilai perusahaan juga dapat diindikasikan oleh Price Earning Ratio. Penelitian berikutnya dapat menggunakan Price to Book Value (PBV) dan Price Earning Ratio (PER) untuk mengindikasikan nilai perusahaan.

\section{Implikasi}

Dalam konteks Signaling Theory, investor dapat merespon informasi positif yang disampaikan oleh manajemen terkait dengan kinerja keuangan perusahaan.. Informasi positif seperti peningkatan profitabilitas (ROE dan ROA), peningkatan pendapatan per lembar saham (EPS) diharapkan dapat direspon oleh investor dalam keputusan investasinya. Pun demikian dengan informasi negatif seperti peningkatan hutang perusahaan yang diindikasikan oleh rasio hutang (DER), juga diharapkan dapat direspon oleh investor sebagai sinyal untuk lebih hati-hati dalam melakukan keputusan investasinya.

\section{REFERENSI}

Apriliyanti, Devia Amirta. (2015). Analisis Pengaruh Kinerja Keuangan Terhadap Harga Saham Perusahaan Perbankan di Bursa Efek Indonesia, Naskah Publikasi Fakultas Ekonomi dan Bisnis Universitas Muhammadiyah Surakarta.

Arkan, Thomas. (2016). The Importance of Financial Ratios in Predicting Stock Price Trends: A Case Study in Emerging Markets, Finanse, Rynki Finansowe. Ubezpieczenia. 79(1).

Arifianto, M., \& Chabachib, M. (2016). Analisis Faktor-Faktor yang Mempengaruhi Nilai Perusahaan (Studi Kasus Pada Perusahaan yang Terdaftar pada Indeks LQ-45 Periode 2011-2014). Diponegoro Journal of Management, 5(1), 1-12. Retrieved from http://ejournal-s1.undip.ac.id/index.php/dbr

Badan Pusat Statistik. (2012). Indonesian Oil Palm Statistics.

Bodie, Z Kane, A. \& M. A. J. (2015). Investasi Terjemahan Zuliani D.dan Budi Wibowo (Edisi keem). Jakarta: Salemba.

Brigham, E. F., \& Houston, J. F. (2007). Fundamentals of financial management (Dasar-dasar Manajemen Keuangan).

Brigham, E. F., \& Houston, J. F. (2011). Dasar-dasar manajemen Keuangan (Buku 2 - Edisi 11). In Salemba Empat.

Cahyaningrum, Y. W., \& Antikasari, T. W. (2017). Pengaruh Earning per Share, Price to Book Value, Return on Asset, dan Return on Equity terhadap Harga Saham Sektor Keuangan. Journal Economia, 13(2), 191.

Endang Mahpudin, S. (2016). Faktor Faktor Yang Mempengaruhi Nilai Perusahaan (Studi empiris Pada Perusahaan Manufaktur yang terdaftar di Bursa Efek Indonesia). Jurnal Riset Keuangan Dan Akuntansi, 2(2), 56-75.

Fitriani, Ramadhani Srifitra. (2016). Pengaruh NPM,PBV, dan DER Terhadap Harga Saham pada Perusahaan Sub Sektor Makanan dan Minuman di Bursa Efek Indonesia. e-Journal Administrasi Bisnis. 4(3)

Ghozali, I. (2011). "Aplikasi Analisis Multivariate Dengan Program SPSS." Semarang: Badan Penerbit Universitas Diponegoro

Gultom, R., \& Wijaya, S. W. (2014). Analisis Faktor Faktor yang Mempengaruhi Nilai Perusahaan Farmasi di Bursa Efek Indonesia periode 2008-2011. Jurnal Wira Ekonomi Mikroskil, 3(1), 51-60.

Ismayana, P. (2020). Pengaruh Current Ratio, Debt to Equity Ratio dan Return on Equity terhadap Price Earning Ratio dengan Price to Book Value sebagai Variabel Intervening pada 
Perusahaan Sub-Sektor otomotif dan Komponen yang Terdaftar di Bursa Efek Indonesia. Universitas Muhammadiyan Sumatera Utara.

Kusumawati, Rita dan Ade Sudento. 2005. Analisis Pengaruh Profitabilitas (ROE), Ukuran Perusahaan (Size) dan Leverage Keuangan (Solvabilitas) terhadap tingkat underpricing pada penawaran perdana (Initial Public Offering / IPO) Di Bursa Efek Jakarta. Utilitas. Vol. 13, No. 1.

Listari, S. (2018). Analisis Faktor - Faktor yang Mempengaruhi Nilai Perusahaan pada PerusahaanPerusahaan yang Terdaftar Dalam Indeks LQ45 di Bursa Efek Indonesia. Jurnal Ilmiah Manajemen Kesatuan, 6(1), 051-060.

Marlina, T. (2013). Pengaruh Earning Per Share, Return On Equity, Debt To Equity Ratio dan Size Terhadap Price To Book Value. Jurnal Ilmiah Akuntansi Kesatuan, 1(1), 59-72.

Ministry of Agriculture. (2019). Tree Crop Estate Statistics of Idonesia 2018-2020. Secretariate of Directorate General of Estates, 1-82.

Mutammimah. (2020). Faktor-Faktor Yang Mempengaruhi Nilai Perusahaan (Studi Empiris Pada Perusahaan Manufaktur Yang Terdaftar Di BEI tahun 2013-2017). Maksimum Media Akuntansi Universitas Muhammadiyah Semarang, 10(1), 64-84.

Najmiyah. Edy Sujana. Ni Kadek Sinarwati. (2014). Pengaruh Price to Book Value (PBV), Price Earning Ratio (PER), dan Debt to Equity Ratio (DER) Terhadap Return Saham pada Industri Real Estate dan Property yang Terdaftar di Bursa Efek Indonesia Periode 20092013. e-Journal S1 Ak Universitas Ganesha. 2(1)

Permata, Irene Silvia, et al. (2013). Penilaian Saham Dengan Menggunakan Metode Price Earning Ratio (PER) dan Price Book Value (PBV). Malang.

Prasetyorini, Bhekti Fitri. 2013. Pengaruh Ukuran Perusahaan, Leverage, Price Earning Ratio, dan Profitabilitas Terhadap Nilai Perusahaan. Jurnal Ilmu Manajemen. Vol. 1, No.1

Putriana, M. (2019). Pengaruh Price To Book Value (PBV), Debt To Equity Ratio (DER), Return on Assets (ROA) Terhadap Price Earning Ratio (PER) pada Perusahaan Sub Sektor Plastik dan Kemasan Yang Terdaftar di Bursa Efek Indonesia. J-MAS (Jurnal Manajemen Dan Sains), $4(1), 82$.

Rahayu, M., \& Sari, B. (2018). Faktor-Faktor Yang Mempengaruhi Nilai Perusahaan. IKRAITHHumaniora, 2(2), 69-76. https://doi.org/10.37932/ja.v9i2.154

Sembiring, S., \& Ita, T. (2019). Faktor-Faktor yang Mempengaruhi Nilai Perusahaan. Jurnal Bisnis Dan Akuntansi, 21(1), 208.

Subramanyam, K. R. dan J. J. W. (2013). Analisis Laporan Keuangan (Edisi 10.). Jakarta: Salemba Empat.

Sudaryanti, Dedeh \& Sahroni, N. (2016). pengaruh Return On Equity (ROE) dan DEbt to Equity Ratio (DER) Terhadap Price Earning Ratio (PER) (Studi Empiris pada PT. Holcim Indonesia Tbk.). Jurnal Ekonomi Manajemen, 2 No. 1, 40-47.

Sugiarto, Rengga Jeni Ery. (2014). Pengaruh DER, ROA Terhadap Harga Saham pada Perusahaan Telekomunikasi di BEI. Jurnal Ilmu \& Riset Manajemen. 3(9).

Suherman, \& Siburian, A. (2013). Pengaruh Earning Per Share, Debt to Equity Ratio, Return On Equity, dan Price To Book Value Terhadap Return Saham (Studi Kasus Pada Perusahaan Industry Food and Beverages yang Terdaftar di Bursa Efek Indonesia). Jurnal Riset Manajemen Sains Indonesia (JRMSI), 4(1), 16-30.

Sulistyawati, D. P. dan M. (2016). Analisis Pengaruh Return On Equity, Debt to Equity Ratio, dan Current Ratio terhadap Price Earning Ratio. Diponegoro Journal Of Management, 5(4), 1 12.

Utomo, N. A. (2016). Faktor-Faktor yang Mempengaruhi Nilai Perusahaan pada Perusahaan Indeks LQ45 Di Bursa Efek Indonesia. Dinamika Akuntansi, Keuangan Dan Perbankan, 5(1), 82-94.

Wardiningsih, R. 2019. (2019). Pengaruh Earning Per Share , Price To Book Value Dan Economic Vaue Added Terhadap Return Saham. PENSA: Jurnal Pendidikan Dan Ilmu Sosial, 1(2), 335347. 
Wahyuni, Tri, dkk. 2013. Faktor-Faktor Yang Mempengaruhi Nilai Perusahaan di Sektor Property, Real Estate, \& Building Construction Yang Terdaftar di BEI Periode 2008 - 2012. Calyptra : Jurnal Ilimiah Mahasiswa Universitas Surabaya. Vol. 2, No. 1.

Weston, J. Fred dan Thomas E. Copeland. 2010. Dasar-Dasar Manajemen Keuangan. Jakarta : Erlangga.

Sumber Internet

//www.wartaekonomi.co.id/read318543/kondisi-minyak-sawit-tahun-2021-beginiproyeksinya

\section{DECLARATIONS}

\section{Funding}

The authors received no financial support for the research and publication of this article.

\section{Conflicts of interest/ Competing interests:}

The authors have no conflicts of interest to declare that are relevant to the content of this article.

Data, Materials and/or Code Availability:

Data sharing is not applicable to this article as no new data were created or analyzed in this study.

\section{How to cite this Article}

Mappadang, A., Mappadang, J., \& Wijaya, A. (2022). Efek Kinerja Keuangan Dan Kebijakan Keuangan Terhadap Nilai Perusahaan. AKURASI: Jurnal Riset Akuntansi Dan Keuangan, 3(3), 137 150. https://doi.org/10.36407/akurasi.v3i3.529 